\title{
Designing for Standardizing on Six Sigma Education
}

\author{
Jing Lu \\ Email:1u59@purdue.edu \\ Chad Laux, PhD \\ Email: claux@purdue.edu \\ Aswathy Suresh \\ Email: Suresh@purdue.edu
}

Department of Technology Leadership and Innovation, Purdue University

\begin{abstract}
Purpose: This study evaluated differing sources of the Lean Six Sigma body of knowledge with the purpose of standardizing on learning outcomes for a Black Belt graduate level course.

Design/Methodologies/Approach: Through a systematic literature review and a reverse curriculum design model, three associations that maintain Lean Six Sigma standards (ISO, ATMAE, ASQ) were compared for the development of learning outcomes that were most similar among the standards bodies and evaluated against Bloom's taxonomy.
\end{abstract}

Findings: Based upon the curriculum model, seven enduring understandings were developed about learning DMAIC, project management, and teamwork.

Practical Implications: The outcomes of this study are the identification of those skills and knowledge that are in congruence with the ISO Six Sigma standards, ATMAE body of knowledge, and ASQ's Black Belt certification. A common framework of these standards groups, for introducing Lean Six Sigma into higher education may serve as a reference for the educator.

Originality: There is limited research in Six Sigma standardization applied to curriculum development.

Keywords: Six Sigma, higher education, standards, curriculum

Paper Type: Conference 


\section{Introduction}

As the $21^{\text {st }}$ century proceeds, new approaches to student learning are demanded from higher education. Increasing universal access to students of every type of challenges pedagogy, away from traditional lecture hall style 'sage on the stage' approach to more active classroom (Kreber, 2007). What underlies the scholarship of teaching and learning (SoTL) are considerations of the increasing variety of students, with the goal of supporting their success, through enhancement of the learning experience (Kreber, 2007). Further, (Kreber, 2007) recognizes a tendency for SoTL to be exclusive to discipline specific domains. However, (Antony, 2004) notes that this is not the case in the Lean and Six Sigma domain.

Antony (2008) additionally describes how students of these schools would benefit true value of practically useful quality and process improvement tools, which require statistical skills and expertise. LSS has been studied on how to improve delivery of curriculum, though not within the discipline itself in a study of LSS for improving HEI operations (Hess \& Benjamin, 2015). In another reflective study, Hess \& Benjamin (2015) note that the customer focus of LSS aligns well with student focus of HEIs. The major findings, with regards to curriculum delivery, note that LSS could support the idea of student competencies, rather than credit hour, to assess student learning (Hess \& Benjamin, 2015). However, there are a few studies about SoTL and the LSS discipline. A few of those SoTL studies are noted below.

In comparing two courses between two institutions, Furterer (2007) studied the teaching effectiveness of students learning Six Sigma. Furterer (2007) finds that the use of project based learning, as an instructional strategy, was valued by students as real-world experiential learning, though, more effective by graduate than undergraduate students. However, (Furterer, 2007) notes that it was difficult for instructors to serve as project coach and instructor, both roles crucial to the successful adoption of Six Sigma. (Leduc et al., 2010) also studies how students learn LSS through project-based learning. In partnering with various industries, students completed their projects, though not at a demonstrative professional level. Regardless, (Leduc et al., 2010) notes that students in the process improvement field would be ahead of their peers. (Zhan \& Porter, 2008) discuss teaching Six Sigma as part of another course, this time an undergraduate Electrical Engineering Technology (EET) course where students applied the Six Sigma methodology, Define-Measure-Analysis-Implement-Control (DMAIC), as a problem-solving approach rather than one utilized within EET to a design project. Students were positive with regard to Six Sigma but stated that a more focused project based approach would help understand the content (Zhan $\&$ Porter, 2008). In another capstone, or culminating, course, (Vila-Parrish \& Raubenheimer, 2012) study how a structured framework of project management, mimicking industry practices, impacts student problem solving process. By developing an approach that integrates project management with LSS methods, (Vila-Parrish \& Raubenheimer, 2012) found that students assessed their own abilities with regard to communications and project management significantly higher at the end of the term. Again, a project-based approach, whereby projects were industry sponsored, was the instructional strategy (Vila-Parrish \& Raubenheimer, 2012). Finally, in a study by (Kanigolla et al., 2014), the authors' integrated projects based learning (PBL) into two courses: one quality and undergraduate and the other graduate and Six Sigma. The introduction of PBL to these courses demonstrated that the industry-sponsored project had a positive impact in students' understanding of course concepts and applying the theory to their own projects. Clearly, the component of PBL in learning LSS is crucial. 


\section{Methodology}

This paper is based upon teaching undergraduate students Lean Six Sigma that is aligned with the Black Belt body of knowledge, with a few exceptions: namely, the addition of significance testing and measurement study analyses. The course is required for students in the Industrial Engineering Technology, Supply Chain Management Technology, and Healthcare Policy and Management major areas of study. Over the course of the semester, students learn LSS through a practitioner application of DMAIC to an industry related project. These projects may be profit or mission related organizations where a substantial portion of the course assessment is how students apply Lean and Six Sigma to their own projects. Final project evaluations include poster session and technical report. The course is delivered face to face, but with content delivered via course management system, Blackboard. Instructor face to face time (or what may be considered lecture) is held for active learning through student participation rather than attending efforts. The lab portion of the course is focused on applying the principles of Lean Six Sigma through case study, project efforts, or problem based learning. Minitab is also introduced to the students where they learn the basics of the program as applied to statistical thinking required of Six Sigma practitioners (Antony, 2008). The course design followed a reverse curriculum model, a process that the enduring understandings that students should have at the end of the course (Wiggins, 2005). At the end of the semester, students are issued an internal Black Belt certificate of completion, if they complete the project efforts in class and have a ' $\mathrm{B}$ ' grade or above. While (Gore, 2004), notes that certification has a long tradition in higher education, the principles of the course are based upon project based learning (PBL), the comprehensive effort is designed to engage students in investigation of authentic problems (Blumenfeld et al., 1991). The DMAIC project that the students conducted is based upon project objectives, strategic business case, and problem statement to define the project, which is all up to the student as part of their own design effort. Project activities result in a series of artifacts, in this study milestone completions, which result in a final product (Blumenfeld et al., 1991).

The researchers conducted a detailed analysis of the Black Belt body of knowledge in three major Six Sigma organizations: American Society for Quality (ASQ), International Organization for Standardization (ISO), and Association of Technology, Management and Applied Engineering (ATMAE). The three organizations are globally reputable organizations that certify Six Sigma certifications to candidates who pass their standards. The books of knowledge in the three organizations share similarities and differences in learning outcomes and tasks for each phase of Six Sigma projects. The researchers identified the common themes in the three books of knowledge as the required knowledge for teaching Black Belt Six Sigma in classroom. The Figure 1 illustrates the concept of the method. The size of the overlaps in the Venn diagram does not represent the volume of the knowledge. 


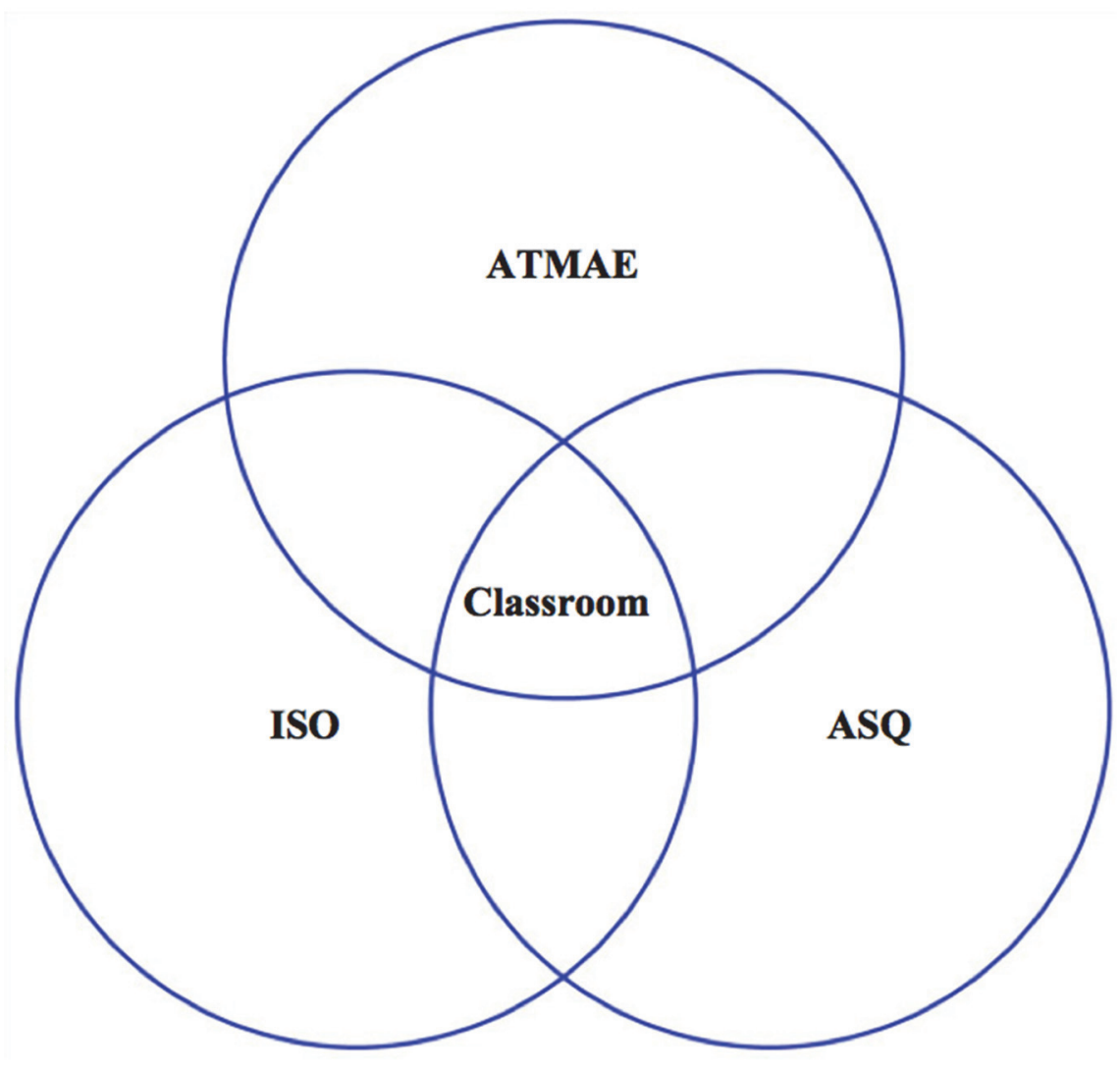

Figure 1. Method For Define Six Sigma Black Belt for Classroom (American Society for Quality, 2007; Lawrence \& Miller, 2015; British Standards Institute, 2011)

The researchers categorized the learning objectives and process improvement tools by bloom's taxonomy and providing a completely revised and new framework which includes all the important knowledge areas from the above three organizations. Bloom's taxonomy was established to build a classification of cognitive skills with six categories: knowledge, comprehension, application, analysis, synthesis, and evaluation (Adams, 2015). The six categories are ordered from requiring less cognitive processing to higher degree of cognitive processing. Keeping the original concept, Anderson et al (2001) revised the six categories to: remembering, understanding, applying, analyzing, evaluating and creating. Remembering is the foundation level of learning, which includes recall specific knowledge (Davidson and Baldwin, 2005). Understanding is the second level of the taxonomy, which involves the learner understand the communication and how to use the material without relating to additional information (Bloom et al., 1956). Applying is the third level of the learning, involves applying material learned in one subject to a similar or predictable problem or implementing them in new situations (Bloom et al., 1956; Anderson et al, 2001). Analyzing is the fourth level of the taxonomy. It includes breaking the communication into logical relations among materials 
(Bloom et al., 1956). Evaluating requires learners to make judgments about the value of material and determine if a process has logic consistent (Bloom et al., 1956). Creating, the highest level of hierarchy, involves putting disparate pieces by a not previously evident structure to form a new whole. (Bloom et al., 1956).

\section{Results}

Through the comparison and analysis, the researchers identified seven major enduring outcomes of Six Sigma teaching curriculum ((Wiggins, 2005):

1. Understands project management.

2. Team management skills.

3. Create Six Sigma Define phase artifacts.

4. Create Six Sigma Measure phase artifacts.

5. Create Six Sigma Analyze phase artifacts.

6. Create Six Sigma Improve phase artifacts.

7. Create Six Sigma Control phase artifacts.

In addition to the 7 learning objectives, the researchers identified detailed objectives for each learning objectives. The learning objectives require different levels of cognitive skills for Six Sigma learner. The researchers applied Bloom's Taxonomy method to determine the cognitive skill levels for each objective. According to the Bloom's Taxonomy cognitive level, the researchers designed corresponding teaching methodologies to support the learning objectives that were identified (Bloom, 1956; Adams, 2014).

\section{Conclusions}

A detailed study was conducted as a two-stage study. The first part involves understanding the knowledge areas that are essential for a Black Belt. This included observing a Black Belt class and the lab work associated with it. The study focuses on analyzing the body of knowledge of three main organizations, ASQ, ATMAE and ISO. The second part includes assigning Bloom's taxonomy principles and assigning active classroom techniques to help the students learn the given learning objectives in a more efficient way. The research proposes a framework for conducting Six Sigma Black Belt education in the field of higher learning.

\section{References}

Adams, N.E., 2015. Bloom's taxonomy of cognitive learning objectives. Journal of the Medical Library Association, 103(3), p.152.

Anderson, L.W., Krathwohl, D.R. and Bloom, B.S., 2001. A taxonomy for learning, teaching, and assessing: A revision of Bloom's taxonomy of educational objectives. Allyn \& Bacon.

Antony, J., 2004. Some pros and cons of six sigma : an academic perspective. International Journal of Productivity and Performance Management, 61(6), pp.691-698.

Antony, J., 2008. What is the role of academic institutions for the future development of Six Sigma? International Journal of Productivity and Performance Management, 57(1), pp.107-110. 
American Society for Quality, 2007. American society for quality Six Sigma black belt body of knowledge. Available from: http://asq.org/cert/resource/docs/sixsigma_bok_2007.pdf

Bloom, B.S., 1956. Taxonomy of educational objectives. Vol. 1: Cognitive domain. New York: McKay, pp.20-24.

Blumenfeld, P. et al., 1991. Motivating Project-Based Learning: Sustaining the Doing, Supporting the Learning. Educational Psychologist, 26(3 \& 4), pp.369-398.

British Standards Institute (BSI), 2011. BS ISO 13053-1: 2011. Quantitative Methods in Process Improvement-Six Sigma.

Davidson, R.A. and Baldwin, B.A., 2005. Cognitive skills objectives in intermediate accounting textbooks: Evidence from end-of-chapter material. Journal of Accounting Education, 23(2), pp.79-95.

Furterer, S., 2007. INSTRUCTIONAL STRATEGIES AND TOOLS TO TEACH SIX SIGMA TO ENGINEERING TECHNOLOGY UNDERGRADUATE STUDENTS Instructional Strategies and Tools to Teach Six Sigma to Engineering Technology Undergraduate Students. In Proceedings of the American Society for Engineering Education Conference.

Gore, D.W., 2004. Is Six-Sigma Certification Appropriate for the Classroom ? In Proceedings of the American Society for Engineering Education Conference.

Hess, J.D. \& Benjamin, B.A., 2015. Applying Lean Six Sigma within the university: opportunities for process improvement and cultural change. International Journal of Lean Six Sigma, 6(3), pp.249-262. Available at: http://dx.doi.org/10.1108/IJLSS-12-2014-0036.

Kanigolla, D. et al., 2014. Enhancing engineering education using project-based learning for Lean and Six Sigma. International Journal of Lean Six Sigma, 5(1), pp.45-61. Available at: http://www.emeraldinsight.com/doi/abs/10.1108/IJLSS-02-2013-0008 [Accessed September 9, $2014]$.

Kreber, C., 2007. What's it really all about? The Scholarship of Teaching and Learning as an Authentic Practice. International Journal for the Scholarship of Teaching and Learning, 1(1), pp.1-4. Available at:

http://academics.georgiasouthern.edu/ijsotl/v1n1/essays/kreber/IJ_Kreber.pdf.

Lawrence, H. and Miller, M.R., 2015. The ATMAE Lean Six Sigma Certification Exam: Why it Matters to You?. Journal of Technology, Management \& Applied Engineering, 31(3).

Leduc, A., Hadley, G. \& Ratzlaff, M., 2010. Immersive learning using Lean Six Sigma methodology in the Manufacturing Engineering Technology capstone course. ASEE Annual Conference and Exposition, Conference Proceedings. Available at:

http://www.scopus.com/inward/record.url?eid=2-s2.0-77955933372\&partnerID=tZOtx3y1. 
Vila-Parrish, A. \& Raubenheimer, D., 2012. Integrating project management, Lean-Six Sigma, and assessment in an industrial engineering capstone course. ASEE Annual Conference and Exposition, Conference Proceedings. Available at:

http://www.scopus.com/inward/record.url?eid=2-s2.0-84865034993\&partnerID=tZOtx3y1.

Wiggins, G. McTighe, J., 2005. Understanding by design., Ascd. Vancouver.

Zhan, W. \& Porter, J., 2008. TEACHING SIX SIGMA IN A COURSE PROJECT Teaching Six Sigma in a Course Project. In Proceedings of the American Society for Engineering Education Conference. 


\section{APPENDIX}

Tables for Enduring Objectives with Bloom's Taxonomy and Teaching Methodologies

\begin{tabular}{|c|c|c|c|}
\hline \multicolumn{2}{|c|}{ Enduring Objectives (EO) } & \multirow{2}{*}{$\begin{array}{l}\text { Bloom's } \\
\text { Taxonomy }\end{array}$} & \multirow{3}{*}{$\begin{array}{l}\text { Teaching Methodologies } \\
\text { Teach Six Sigma lecture; } \\
\text { Case study game; Class } \\
\text { discussion, } \\
\text { Case study based role game: } \\
\text { The role play game assigns } \\
\text { each student a particular role } \\
\text { which includes but not } \\
\text { limited to quality analyst, } \\
\text { proiect manager, technical }\end{array}$} \\
\hline \multirow[t]{5}{*}{$\begin{array}{l}\text { EO1 } \\
\text { Understands } \\
\text { project } \\
\text { management }\end{array}$} & $\begin{array}{l}\text { Objective: } 1 \\
\text { Evaluate and select } \\
\text { the most desirable } \\
\text { six sigma project }\end{array}$ & & \\
\hline & $\begin{array}{l}\text { Objective: } 2 \\
\text { Understands project } \\
\text { prioritization } \\
\text { methods }\end{array}$ & Understanding & \\
\hline & $\begin{array}{l}\text { Objective: } 3 \text { Can } \\
\text { scope projects for } \\
\text { attainability by } \\
\text { KPOV analysis }\end{array}$ & Applying & \multirow{5}{*}{$\begin{array}{l}\text { lead etc. They are given a } \\
\text { real time scenario and a } \\
\text { mock project to handle. The } \\
\text { team starts working to come } \\
\text { up with project requirements, } \\
\text { scope, standardized process } \\
\text { etc. The activity aims to help } \\
\text { the students learn to work as } \\
\text { a team and will also think } \\
\text { about decision making } \\
\text { techniques in case of any } \\
\text { conflicts during this exercise. }\end{array}$} \\
\hline & $\begin{array}{l}\text { Objective: } 4 \text { Identify } \\
\text { and document the } \\
\text { project deliverables }\end{array}$ & Understanding & \\
\hline & $\begin{array}{l}\text { Objective: } 5 \text { Project } \\
\text { selection based on } \\
\text { customer needs }\end{array}$ & Applying & \\
\hline \multirow[t]{2}{*}{$\begin{array}{l}\text { EO2 Applies } \\
\text { team } \\
\text { management } \\
\text { skills }\end{array}$} & $\begin{array}{l}\text { Objective: } 1 \text { Applies } \\
\text { team-building skills } \\
\text { to support successful } \\
\text { performance in a } \\
\text { project }\end{array}$ & Applying & \\
\hline & $\begin{array}{l}\text { Objective: } 2 \text { Selects } \\
\text { team members based } \\
\text { on specific project } \\
\text { requirements }\end{array}$ & Understanding & \\
\hline
\end{tabular}




\begin{tabular}{|c|c|c|c|}
\hline & $\begin{array}{l}\text { Objective: } 3 \\
\text { Understands conflict } \\
\text { resolution for team } \\
\text { decision making }\end{array}$ & Understanding & \\
\hline & $\begin{array}{l}\text { Objective: } 4 \text { Project } \\
\text { selection based on } \\
\text { customer needs }\end{array}$ & Applying & \\
\hline \multirow[t]{4}{*}{$\begin{array}{l}\text { EO3 Creates } \\
\text { SS Define } \\
\text { phase } \\
\text { artifacts }\end{array}$} & $\begin{array}{l}\text { Objective: } 1 \text { Creates } \\
\text { SIPOC process } \\
\text { diagrams, business } \\
\text { process map, and } \\
\text { Pareto diagram of } \\
\text { historical data to } \\
\text { create and refine } \\
\text { project objectives }\end{array}$ & Creating & $\begin{array}{l}\text { Introduction to tools and } \\
\text { techniques of define phase } \\
\text { with a presentation and class } \\
\text { discussion. }\end{array}$ \\
\hline & $\begin{array}{l}\text { Objective: } 2 \text { Creates } \\
\text { CTQ's/CCR's based } \\
\text { upon Voice of the } \\
\text { Customer analysis }\end{array}$ & Creating & $\begin{array}{l}\text { Teach Six Sigma lecture; } \\
\text { Class discussion. }\end{array}$ \\
\hline & $\begin{array}{l}\text { Objective: } 3 \text { Creates } \\
\text { a project charter, } \\
\text { including risk } \\
\text { analysis for } \\
\text { stakeholder } \\
\text { agreements }\end{array}$ & Creating & $\begin{array}{l}\text { An exercise to create project } \\
\text { charter based on a business } \\
\text { requirements and other } \\
\text { information that replicates a } \\
\text { real time scenario. The } \\
\text { exercise will help the } \\
\text { students understand the } \\
\text { framework and content that } \\
\text { goes into a project charter. }\end{array}$ \\
\hline & $\begin{array}{l}\text { Objective: } 4 \text { Applies } \\
\text { GANTT chart for } \\
\text { project management } \\
\text { and critical path } \\
\text { analysis }\end{array}$ & Analyzing & $\begin{array}{l}\text { Group students into teams } \\
\text { and each team has to analyze } \\
\text { a sample case project charter } \\
\text { of a different team and } \\
\text { decide the critical parameters }\end{array}$ \\
\hline $\begin{array}{l}\text { EO4 Creates } \\
\text { SS Measure }\end{array}$ & $\begin{array}{l}\text { Objective: } 1 \text { Creates } \\
\text { Data collection plan } \\
\text { and trains }\end{array}$ & Evaluating & $\begin{array}{l}\text { Teach Six Sigma lecture and } \\
\text { tools for measure phase and } \\
\text { class discussions based on a }\end{array}$ \\
\hline
\end{tabular}




\begin{tabular}{|c|c|c|c|}
\hline $\begin{array}{l}\text { phase } \\
\text { artifacts }\end{array}$ & $\begin{array}{l}\text { stakeholders on data } \\
\text { collection }\end{array}$ & & \multirow{4}{*}{$\begin{array}{l}\text { case study. Case study } \\
\text { focuses on } \\
\text { *Developing the } \\
\text { methodology by which data } \\
\text { will be collected to evaluate } \\
\text { success } \\
\text { *Identifying input, processes, } \\
\text { and output indicators } \\
\text { *Gathering, plotting, and } \\
\text { analyzing current state data }\end{array}$} \\
\hline & $\begin{array}{l}\text { Objective: } 2 \\
\text { Evaluates control } \\
\text { charts, histograms, } \\
\text { trend charts and } \\
\text { analyze the data } \\
\text { statistically for } \\
\text { comprehensive data } \\
\text { description }\end{array}$ & Evaluating & \\
\hline & $\begin{array}{l}\text { Objective: } 3 \\
\text { Performances } \\
\text { capability analysis of } \\
\text { specified processes } \\
\text { for baseline } \\
\text { performance and } \\
\text { reassess project } \\
\text { goals }\end{array}$ & Analyzing & \\
\hline & $\begin{array}{l}\text { Objective: } 4 \\
\text { Calculates Six Sigma } \\
\text { process performance } \\
\text { metrics like DPMO, } \\
\text { PPM, DPU and RTY }\end{array}$ & Evaluating & \\
\hline & $\begin{array}{l}\text { Objective: } 5 \\
\text { Conducts } \\
\text { measurement study } \\
\text { analysis }\end{array}$ & Creating & $\begin{array}{l}\text { Case study and class } \\
\text { discussions. }\end{array}$ \\
\hline \multirow[t]{2}{*}{$\begin{array}{l}\text { EO5 Creates } \\
\text { SS Analyze } \\
\text { phase } \\
\text { artifacts }\end{array}$} & $\begin{array}{l}\text { Objective: } 1 \\
\text { Conducts root cause } \\
\text { analysis to identify } \\
\text { gaps between } \\
\text { baseline performance } \\
\text { and target and } \\
\text { identifies KPIV's via } \\
\text { C\&E diagramming }\end{array}$ & Creating & \multirow[t]{2}{*}{$\begin{array}{l}\text { Case study; Class discussion; } \\
\text { Teach Six Sigma lecture. } \\
\text { Students create cause and } \\
\text { effect diagram based on a } \\
\text { case. }\end{array}$} \\
\hline & $\begin{array}{l}\text { Objective: } 2 \text { Creates } \\
\text { hypotheses for } \\
\text { testing for root cause } \\
\text { confirmation and } \\
\text { risk analysis of type } \\
\text { I and II errors }\end{array}$ & Creating & \\
\hline
\end{tabular}




\begin{tabular}{|c|c|c|c|}
\hline & $\begin{array}{l}\text { Objective: } 3 \\
\text { Constructs } \\
\text { confidence intervals } \\
\text { for large and small } \\
\text { sample data sets }\end{array}$ & Evaluating & \\
\hline & $\begin{array}{l}\text { Objective: } 4 \text { Confirm } \\
\text { root cause(s) through } \\
\text { significance testing, } \\
\text { utilizing correct test, } \\
\text { based upon data type } \\
\text { (such as ANOVA, } \\
\text { Chi-square, } \\
\text { regression) }\end{array}$ & Evaluating & \\
\hline & $\begin{array}{l}\text { Objective: } 5 \\
\text { Conducts process } \\
\text { value analysis using } \\
\text { business process } \\
\text { map to identify } \\
\text { waste and process } \\
\text { flow barriers }\end{array}$ & Creating & \\
\hline \multirow[t]{4}{*}{$\begin{array}{l}\text { EO6 Creates } \\
\text { SS Improve } \\
\text { phase } \\
\text { artifacts }\end{array}$} & $\begin{array}{l}\text { Objective: } 1 \\
\text { Understand the } \\
\text { Design of } \\
\text { Experiments } \\
\text { principles and } \\
\text { terminologies }\end{array}$ & Understanding & \multirow{4}{*}{$\begin{array}{l}\text { Case Study; Class } \\
\text { Discussions; Teach Six } \\
\text { Sigma lecture. } \\
\text { * Jigsaw Activity: On the } \\
\text { basis of the case, teams are } \\
\text { split up. Each team is } \\
\text { assigned a particular phase of } \\
\text { DMAIC. The students from } \\
\text { each team have to come up } \\
\text { with the issue that needs to } \\
\text { be addressed in the case for } \\
\text { their specific phase and the } \\
\text { teams have to merge all the } \\
\text { parts and create a final } \\
\text { report. Students will map out } \\
\text { the entire process structure of } \\
\text { DMAIC at the end of the } \\
\text { activity. }\end{array}$} \\
\hline & $\begin{array}{l}\text { Objective: } 2 \text { Plan } \\
\text { and conduct DOE by } \\
\text { choosing appropriate } \\
\text { design methods, } \\
\text { factors and } \\
\text { measurement } \\
\text { methods }\end{array}$ & Evaluating & \\
\hline & $\begin{array}{l}\text { Objective: } 3 \text { Applies } \\
\text { Lean methods like } \\
\text { waste elimination, } \\
\text { error-proofing, etc. } \\
\text { for process } \\
\text { improvement }\end{array}$ & Applying & \\
\hline & $\begin{array}{l}\text { Objective: } 4 \text { Creates } \\
\text { solution matrix for }\end{array}$ & Creating & \\
\hline
\end{tabular}




\begin{tabular}{|c|c|c|c|}
\hline & $\begin{array}{l}\text { criterion based } \\
\text { decision making for } \\
\text { process } \\
\text { improvements }\end{array}$ & & \\
\hline & $\begin{array}{l}\text { Objective: } 5 \\
\text { Develops robust } \\
\text { solutions through } \\
\text { Process FMEA and } \\
\text { Design FMEA }\end{array}$ & Creating & \\
\hline & $\begin{array}{l}\text { Objective: } 6 \text { Develop } \\
\text { plans to implement } \\
\text { improvement } \\
\text { strategies }\end{array}$ & Evaluating & \\
\hline \multirow[t]{5}{*}{$\begin{array}{l}\text { E07 Creates } \\
\text { SS Control } \\
\text { phase } \\
\text { artifacts }\end{array}$} & $\begin{array}{l}\text { Objective: } 1 \\
\text { Understands change } \\
\text { management } \\
\text { principles }\end{array}$ & Applying & \multirow{5}{*}{$\begin{array}{l}\text { Teach Six Sigma lecture; } \\
\text { Case study and go around } \\
\text { discussion } \\
\text { Team activity: Create a } \\
\text { dashboard management } \\
\text { system based on a case } \\
\text { given. Create a one page } \\
\text { final document involving all } \\
\text { the phases and a detailed } \\
\text { work on control phase. } \\
\text { * Control charts are applied } \\
\text { to monitor process stability } \\
\text { and process control. Control } \\
\text { charts are two-dimensional } \\
\text { graphs that one axis } \\
\text { represents the process } \\
\text { performance and the other } \\
\text { axis represents time. If a } \\
\text { process is stable or under } \\
\text { control, the plotted points } \\
\text { should within control limits. } \\
\text { If there is a source of } \\
\text { variation, there will be } \\
\text { deviation of observation from } \\
\text { systemic patterns. }\end{array}$} \\
\hline & $\begin{array}{l}\text { Objective: } 2 \text { Creates } \\
\text { statistical process } \\
\text { control charts* for } \\
\text { classification of } \\
\text { problems through } \\
\text { action }\end{array}$ & Analyzing & \\
\hline & $\begin{array}{l}\text { Objective: } 3 \text { Defines } \\
\text { visual controls } \\
\text { elements for } \\
\text { dashboard } \\
\text { management }\end{array}$ & Understanding & \\
\hline & $\begin{array}{l}\text { Objective: } 4 \text { Develop } \\
\text { a Process Control } \\
\text { plan to sustain } \\
\text { recommended } \\
\text { improvements. }\end{array}$ & Creating & \\
\hline & $\begin{array}{l}\text { Objective: } 5 \\
\text { Conducts fiscal } \\
\text { analysis through } \\
\text { COPQ }\end{array}$ & Applying & \\
\hline
\end{tabular}




\begin{tabular}{|l|l|l|l|}
\hline & $\begin{array}{l}\text { Objective: 6 } \\
\text { Understands mistake } \\
\text { proofing principles }\end{array}$ & Understanding & \\
\hline & $\begin{array}{l}\text { Objective: 7 Creates } \\
\text { standard work } \\
\text { documentation and } \\
\text { training for } \\
\text { sustainability }\end{array}$ & Creating & \\
\hline
\end{tabular}

